\title{
Status of Organic Farming in Agro Ecosystems in India
}

\author{
P. K. Shetty', M. B. Hiremath ${ }^{1,2 *}$ and M. Murugan ${ }^{1}$ \\ 'School of Natural Sciences and Engineering, National Institute of Advanced Studies, Indian Institute \\ of Science Campus, Bangalore 560012; murigendra@gmail.com, pkshetty17@gmail.com \\ ${ }^{2}$ KLES Kidney Foundation, KLE University's JN Medical College, \\ KLES Dr Prabhakar Kore Hospital \& MRC, Belgaum 590010
}

\begin{abstract}
Organic farming is the form of crop growing that relies on techniques like crop rotation, green compost, manure and biological pest control. This study was an initial attempt to know the status of organic farming in pesticide use predominant 28 districts in 12 Indian states. Doctors, pesticide vendors and agricultural officers of regions were interviewed to study the status of organic farming in the selected areas. Data were collected through pre-tested schedules by trained field investigators. A total of 1577 samples from 290 randomly selected villages were keyed in to Visual Basic front end in MS Access data base. In this study only $3 \%$ of the respondents across the country reported that they had practiced organic farming only, whereas $51 \%$ of respondents practiced chemical farming and $46 \%$ of respondents had taken up both organic and chemical farming. Appropriate research and extension services need to be developed to make available to farmers all the relevant information on organic farming.
\end{abstract}

Keywords: Organic Farming, Pesticide, Fertiliser.

\section{Introduction}

According to International Federation of Organic Agriculture Movements (IFOAM) "Organic agriculture is a production system that sustains the health of soils, ecosystems and people. It relies on ecological processes, biodiversity and cycles adapted to local conditions, rather than the use of inputs with adverse effects. Organic agriculture combines tradition, innovation and science to benefit the shared environment and promote fair relationships and a good quality of life for all involved". The irrigated areas of India account for 35 percent of the total cropped area and here intensive cultivation of crops with extensive use of chemical inputs can be seen. In contrast, remaining 65 percent of cropped area is still rainfed and here the cultivation is largely organic. A recent report stated that in India about
1,426 farms are certified as organic (2). According to the FAO the country produces only 14,000 tonnes of organic produce from certified organic farms. In fact, the country has more areas of organic farms than officially certified and it produces more organic food than estimated by FAO. Though the produce of many farmers is truly organic, it was observed it was not recognised as such. This is because the farmers have not registered their name or may not have paid the required fee to gain official certification [8]. Traditional farming practices maintain a rich agro-biodiversity, ensure the soil fertility through periodical addition of organic manure, and are in perfect harmony with nature. In these systems the soil supported a good population of microorganisms like bacteria, fungi, protozoa and a host of other organisms that sustain soil health. In modern agriculture, chemical fertilisers are extensively used in order

*Corresponding author:

M. B. Hiremath (murigendra@gmail.com) 
to increase the yield. Excessive use of these chemicals has adverse effect on the soil micro-flora and fauna. Good crop management practices, such as, proper spacing, tillage, deep ploughing and mixed cropping are lacking in these regions. Good agricultural practices are necessary to improve soil fertility and reduce pest attack.

\section{Methods}

\subsection{Study Area}

The study was carried out in 28 districts from 12 Indian states selected based on the type of crops grown etc. The focus was on farmers and agricultural labourers who handle pesticides in crops such as paddy, cotton, sugarcane, wheat, apple, pomegranate, mango, grapes and vegetables covering different agro-ecological zones in India. Primary data were collected from farmers, agricultural labourers, pesticide vendors and agricultural officers with the help of pre-tested schedules. A total of 1577 samples from 290 randomly selected villages across the 12 Indian states were drawn during 2004-2007. Data collected through schedules were keyed in to Visual Basic front end in MS Access data base. Schedules of farmers, agricultural officers, vendors, labourers had a separate software package and data were then analysed through suitable statistical technique.

\section{Results}

In some villages in the study area, the easy availability of agro-inputs particularly chemical fertilizers and pesticides in the markets, and the quick returns have motivated farmers to go in for purely chemical-based farming. The unhealthy competition among some farmers to achieve higher yields using increased application of fertilizers and pesticides gave an impetus to agro-chemical markets. Also, excessive dependence on plant protection chemicals to enhance agricultural production has created agro-ecological imbalances in these regions. The limited availability of organic manure and slow action of bio-pesticides are some of the important factors that discourage the farmers from using eco-friendly methods. In this study only $3 \%$ of the respondents across the country reported that they had practiced organic farming only, whereas $51 \%$ of respondents practiced chemical farming and $46 \%$ of respondents had taken up both organic and chemical farming (Figure 1). The number and popularity of farmers' markets in some places have grown concurrently with organic production and consumer interest in locally for organically produced

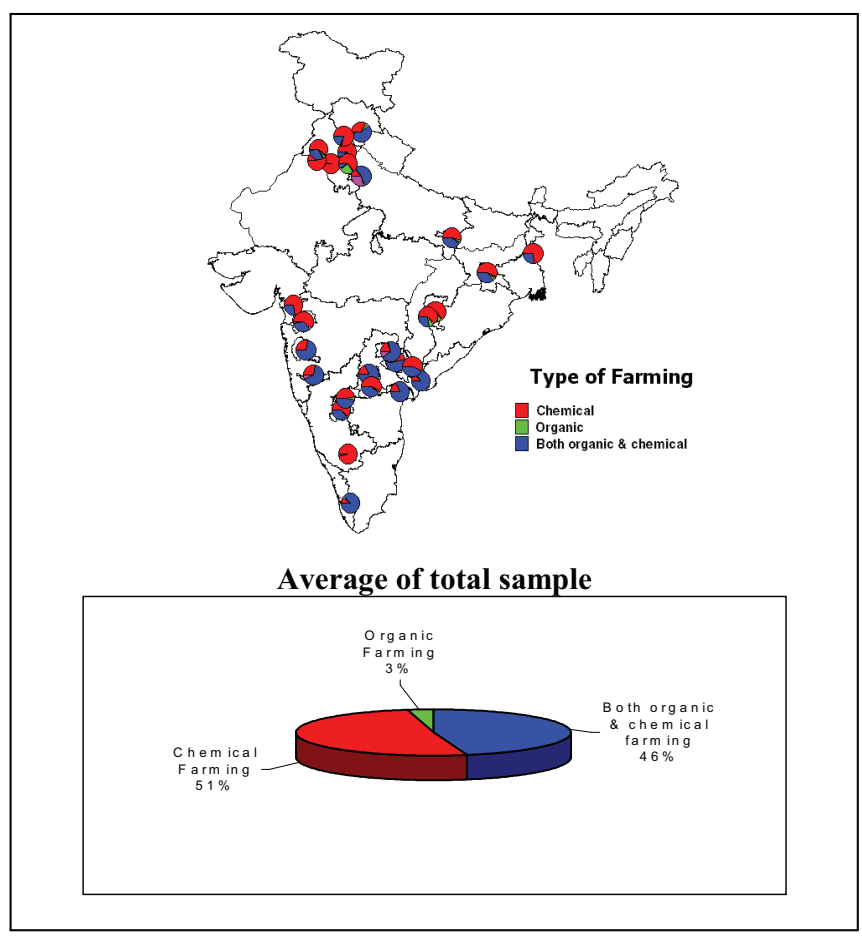

Figure 1. Type of Farming in agro-ecological regions in the country.

food material. The successful organic farmers like Gurnam Singh, Amar Singh and others in the districts felt that there is a vast export potential for labeled organic agricultural products.

Certification of organic produce is an integral part of the National Standards in some developed countries like Australia and USA. It will ensure that the produce can be verified along the production and distribution chain. Monitoring compliance through regular inspection programs will provide product integrity and enhance consumer confidence in the final product. The standard should aim at protecting consumers against deception and fraud in the market and unsubstantiated product claims; protect producers of organic produce against claims that non-organic agricultural produce is organic; harmonise national provisions for the production, certification, identification and labelling of organic produce; ensure that all stages of production, processing and marketing are subject to inspection and meet minimum requirements; and provide a guide to farmers contemplating a changeover to organic farming.

\section{Organic Farming}

A widely used definition of organic farming is the one provided by the United States Department of Agriculture 
(USDA), which defines it as a "Production system which avoids or largely excludes the use of synthetically compounded fertilizers, pesticides, growth regulators and livestock feed additives. To the maximum extent feasible, organic farming systems rely upon crop rotations, crop residues, animal manure, legumes, green manure, off-farm organic wastes, mechanical cultivation, mineral bearing rocks and aspects of biological pest control to maintain soil productivity and tilth, to supply plant nutrients and to control insects, weeds and other pests."

The concept of organic agriculture is not alien to India. In fact, the first scientific approach to organic farming dates back to the Vedas of the later Vedic period, the essence of which is to live in harmony with, rather than exploit, Mother Nature. More recently, Mahatma Gandhi pioneered organic farming through his constructive programmes in several locations in India. It was the aggressive promotion of the green revolution, which led to a reverse in the spread of the Gandhian movement's organic farming programme. There is evidence to suggest that small farmers, especially in the Third World, are more likely to apply agricultural practices such as crop rotations and mixed cropping, which are the essential building blocks of organic farming. They also usually combine agriculture with livestock rearing and utilize the manure to replenish the soil fertility.

Empirical evidence further suggests that while conventional agriculture goes better with large holdings, organic farming functions better in small farms. A study by Hanson and co-workers [5], comparing grain production in organic vis-a-vis conventional methods, observed that as farm size increases, the advantages of organic rotation become less visible. Further, the study reported that on a smaller scale, organic farming was more profitable and productive than conventional farming.

In India, approximately $70 \%$ of arable land, where rainfed or dry farming is practiced, agro-chemicals are not generally used. According to an estimate made by the Institute of Integrated Rural Development in 2001, only one fifth of the dry land farmers in India use chemical inputs, the rest rely on manure and green compost for maintaining soil fertility. The majority of these people use traditional methods, often in highly heterogeneous and risk-prone marginal environments. In fact, given their situation, these farmers have little choice but to rely upon locally available natural resources to maintain soil fertility and to combat pests and diseases. Whatever may be the reasons, the fact is that the diverse farming systems managed by such small farmers could be considered as organic, as they do not rely on synthetic chemical pesticides or fertilizers and use technologies that optimize nutrient flows and use local resources such as native seeds and traditional knowledge. In technical terms such farms are called 'de-facto organic' (as distinct from certified organic) farms, i.e., farms that rely exclusively on natural methods of building soil fertility and combating pests and diseases, but are not inspected and verified by any organic certification agency [3].

The lucrative market of the developed world has so far acted as the primary driving force behind the development of the 'certified organic' sector, which is still in a nascent stage in India. According to one estimate, in 1999 merely $0.001 \%$ of the total agricultural land in India was under certified organic cultivation. It is predominantly the NGOs and people's organizations that have been spearheading organic agriculture movement in different parts of the country during the last two decades.

The Government of India has set up a special cell under the Agricultural and Processed Food Export Development Authority (APEDA) of the Ministry of Commerce and Industries (MOCI). The MOCI has come out with the 'National Programme of Organic Products' (NPOP) in 2000, and the 'India Organic' logo in 2002. While these initiatives have been undertaken to promote exports of Indian organic products, the Department of Agriculture and Cooperation has formulated a 'National Project on Organic Farming' to promote organic agriculture as part of an exercise to curb the use of chemical pesticides and make agricultural activity more eco-friendly. Shifting to organic farming, even if it promises higher returns in terms of better prices and international acceptability in the long run, may not be preferred by the majority of farmers as they are dependent on the farm for livelihood and any departure would affect them immediately. To make majority of small farmers shift to organic farming, several subsidies have to be given on organic inputs [1]. Such initiatives are a step in the right direction, but they should be weighed against the huge subsidies that the Central Government has been providing for the production and import of chemical fertilizers and pesticides. There is a great potential for organic farming to flourish in this country and given an appropriate institutional and policy framework, it will not be very difficult to promote the existing 'de-facto organic' farms to the category of certified organic farms. This would enable the small farmers to take advantage of the lucrative market for certified organic products in the developed world, which could directly contribute towards the improvement of their economic well-being.

Though respondents are aware of the advantages of eco-friendly farming, only a few of them in the study area 
practice it. Mr. Mudde Gowda is a farmer in Mukunda village in Sindhnoor taluk of Raichur district mainly grows paddy in his field. Mr. Gowda, educated upto the 4th standard, has been practising organic farming for the past 14 years on his 60 acres of land. About 22 years ago, Mr. Gowda was inspired by a lecture on organic farming, but he began to practice in the same only about 14 years ago. He took almost 8 years to take a decision to shift from chemical farming to organic farming. He applies only organic manure to the crops and avoids expensive chemical fertilizers. He uses neem-based pesticides and extracts prepared with Datura, Parthenium etc. to reduce the problems of insect pests. Initially his yields were low, but by these means are now improving. The land he cultivates is rejuvenating to its natural health. His organic produces are in high demand in the local market and they fetch nearly 30 per cent more returns. Mr. Gowda is of the opinion that farmers practicing chemical farming are aware of the fact that organic farming gives better results in the long run. However, they are not willing to take the risk of changing over to organic farming, because a sudden shift may reduce the yield drastically.

Mr. Gurunam Singh, Budha village, Kurukshetra, a graduate in Arts, has been practicing organic farming for the past 6 years on his 40 acres of land. He started organic farming when he failed to control pests and diseases in sugarcane. In the initial 2-3 years he failed to get expected results, but now he is satisfied with the yield. Though Mr. Singh gets comparatively lower yield than those who are practicing chemical farming in this region, his organic produces are in good demand in the local market and they fetch nearly 30 per cent higher returns. Further he is successfully marketing organic seeds to one of the companies in Chandigarh.

It was observed that only $3 \%$ of the respondents from selected districts are practicing organic farming. Some respondents who have dairy as a subsidiary farm enterprise use cattle dung as a source of fuel and do not use it in their fields. Though a large number of respondents are aware of the advantages of eco-friendly farming, for unavoidable reasons, only few of them practice it.

According to Mr. Gurunam Singh, all the crops, which were introduced and grown for the first time in the Budha village, gave good returns in the beginning, but after a few years, the yield gradually decreased because of monoculture and also due to increased incidences of pests and diseases. In an experiment, it was observed that during the first four years of transition from inorganic to organic, there was a decrease in yield, thereafter the yield increased in the subsequent years when the soil regained its adequate biological activities. Besides, improved soil, biological activities in the organic fields play an important role in suppressing weeds, pests and diseases [6]. Though such experiments sound interesting, respondents in the study area are hesitant to change over to organic farming, due to risk involved in the initial period of transition.

Among Indian farmers the usage of bio-pesticides varies depending on the crops. For instance the use of bio pesticides in cardamom (small) and black pepper is very high in Kerala whereas minimal usage has been reported in crops like vegetable crops (carrot and garlic). Most planters in cardamom use bio pesticides for managing major pests and the trend is highly positive. However, the consumption of bio-fertilizers is low even among educated cardamom and pepper farmers in Idukki district. Among biopesticides used in cardamom production system the use of Pseudomonas, Trichoderma, Glomus sp., Bevaria, Metarrhizium and Verticilium has been increasing. One of the reasons for raised use of biopesticides in the recent times is the banning by the state government and limited choices and availability of pesticides, for e.g. phorate was banned and the alternate choice was carbosulphan which is less toxic and poor protection against disease hence farmers prefer biopesticides in place of synthetic pesticides. Grapes cultivation in Cumbum valley (Tamil Nadu) is highly profitable but farmer's preference for biopesticides is very low because many toxic pesticides are available for managing insect pests and diseases.

\section{Economic Benefits from Organic Agriculture}

The reduced use of expensive inputs in organic cultivation normally leads to reduction in the cost of cultivation. The organic farmer avoids expenditure on chemical fertilizers and pesticides and also the labour charges for application of these chemicals. The organic farmer incurs input costs only when the organic manures and bio-pesticides are externally purchased. It was confirmed in the study areas that the produces of organic farmers are in good demand and they get an additional $30 \%$ income as compared to the produces from conventional farming. As a result the respondents in the selected districts who cultivate paddy organically showed slightly higher net income as compared to those following chemical farming (Figure 2). With the increase in awareness/education and subsidies on organic produces there is an enormous potential for increasing the 


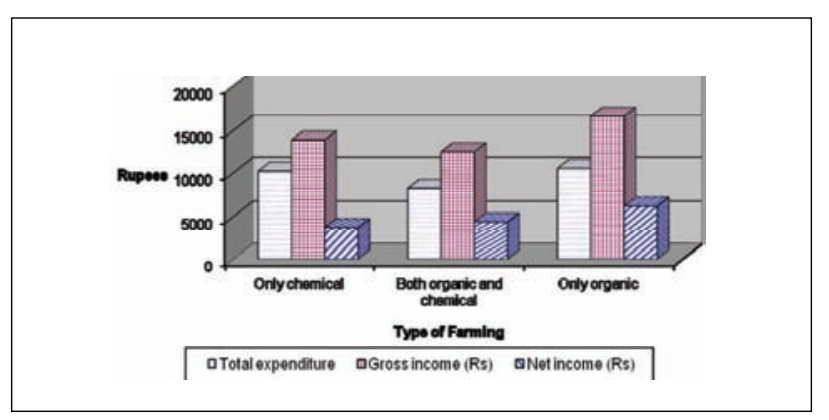

Figure 2. Comparitive cultivation cost \& net income of paddy in the study areas.

area under organic farming. However, small land holdings, increasing population and lack of long-term goal are noted to be key impediments to promote organic farming.

Note: The organic farmers, who were cultivating paddy organically, have been practicing organic farming from 5-14 years. Though organic cultivation did not fetch good profit in the initial years, the respondents reported a gradual increase in profit.

\section{Impact of Farm Animals on Organic Farming}

A large number of small and marginal farmers in the study area expressed their inability to buy and maintain improved breed of animals. Also before the advent of the green revolution period, the residues from traditional varieties of crops provided substantial quantities of fodder for farm animals. Fodder availability was declined after introduction of short-stalked high-yielding varieties. Further, extensive deforestation and conversion of vast pasturelands to agriculture deprived the farm animals of sufficient fodder. There are several other reasons for the decreased dependence on farm animals. The country is losing some of the native breeds of animals that were resistant to diseases. Though the improved breeds produce high quantities of milk, they are susceptible to diseases [5]. Moreover, the increase in the number of small land holdings and the declining area under fodder crops have reduced grazing opportunities. In addition, the use of power tillers and tractors have reduced the dependence of farmers on farm animals, which were the main source of organic manure. In addition, a substantial quantity of organic manure is consumed as domestic fuel, preventing its use as manure. High organic matter content in soil is very essential for balanced soil fertility and productivity, which gives better crop immunity against some pests and diseases. Undernourished plants produce an unbalanced amount of carbohydrates at the expense of proteins and trace minerals. Therefore, insect pests are differentially attracted towards such sweet plants [7].

It was observed that 68.7 percent of respondents were practicing dairy as their subsidiary enterprise. This trend was prominent in few districts such as Sirsa, Hisar, Panipat and Varanasi. Only 6.96 percent of respondents were found practicing poultry and remaining 3 percent of respondents have taken up other subsidiary farming like sericulture, rearing sheep, aquaculture, apiculture and mushroom cultivation $[9,10]$.

In view of the sustainability problems associated with chemical inputs, there is a case to invoke traditional wisdom and work for a judicious blend of modern and traditional technologies in agriculture. A shift in technology away from highly chemical based practices to organic farming can be an answer, but the productivity effect of the shift calls for caution about the likely impact on farmers income [4]. It is important that national and state agricultural policies paved the way for the promotion of organic agriculture on a nation-wide scale. This is the only means that can ensure the sustainability of agriculture in the long run, and at the same time providing a healthier and habitable environment.

Das [3] suggested following the points to ensure agricultural sustainability in the country: Appropriate research and extension services need to be developed to make available to farmers all the relevant information on organic farming, in general, and its specific technical details, in particular; Certification and labeling capacities need to be developed within the country so as to overcome the prohibitive costs involved in getting certification done by external agencies and also certification processes need to be simplified and made accessible to farmers; Biofertilisers, bioagents, biopesticides and other organic inputs need be made available to the small and marginal farmers at sufficient quantities and reasonable prices; Domestic market for organic produces, which is still at a budding stage in this country, need to be encouraged and developed; Marketing linkages, both domestic and international, need to be ensured for resource-poor small farmers. Subsidies and other financial support schemes need to be undertaken to help the small growers bear the initial expenses for converting to 'certified organic' farms. The limitations of this study is a small sample and limited period study in a intensive agriculture areas, further studies are necessary to know the status of organic agriculture different agroecological regions of India. 


\section{References}

1. Babu K L, Guha-Khasnobis B et al. (2003). Impact of globalization on marginal farmers: a case study of coffee farmers of India and Vietnam, ed. UNU (UNU), Helsinki, United Nations University (UNU).

2. Brook and Bhagat G (2004). Organic by Default - The Irony of Organic Farming in India, Available from: http://www. ecoworld.com/technology/organic-farming-in-india. html

3. Das K (2004). Organic: To combat pesticide residues, Available from: http://www.indiatogether.org/2004/mar/agrorganic.htm

4. Ghosh N (2004). Reducing dependence on chemical fertilizers and its financial implications for farmers in India, Ecological Economics, vol 49(2), 149-162.
5. Gupta A, Verma J et al. (1997). Vanishing breeds, Down to Earth, vol 11(15), 27-37.

6. International Federation of Organic Agriculture Movements (IFOAM) (1998). Basic standards for organic production and processing, IFOAM Publications, Tholey-Tholey, Germany.

7. Saxena R D (1996). Report on awareness programmes on pesticides and sustainable agriculture, Part II, New Delhi, 13-42.

8. Sharma A K (2001). A handbook of organic farming, Jodhpur (India): Agrobios.

9. Shetty P K, Murugan M et al. (2010). Farmers' education and perception on pesticide use and crop economies in Indian agriculture, Journal of Experimental Sciences, vol 1(1), 3-8.

10. Shetty P K, Hiremath M B et al. (2011). Farmer's health externalities in pesticide use predominant regions in India, World Journal of Science and Technology, vol 1(4), 1-11. 